\begin{tabular}{lllll} 
ZAPISKI HISTORYCZNE & $-\underset{\text { Teszyt } 2}{\text { TOM }}$ & LXXX & - ROK 2015 \\
\hline
\end{tabular}

http://dx.doi.org/10.15762/ZH.2015.19

ZOFIA MACIAKOWSKA

(Instytut Historii PAN)

\title{
KILKA UWAG \\ NA TEMAT ŚREDNIOWIECZNEGO OSIEKA W GDAŃSKU
}

Słowa kluczowe: Gdańsk, Osiek, średniowiecze, osadnictwo, Kanał Raduni

Gdański Osiek, do którego odwołuje się dziś jedynie nazwa jednej z ulic, był peryferyjną dzielnicą Gdańska zamieszkiwaną przez ubogą ludność. Co najmniej od lat trzydziestych XV do XVI w. stanowił odrębną gminę miejską ${ }^{1}$. Około połowy XVI w. rozciągał się na wschód od placu kościoła św. Katarzyny i ul. Małe Mniszki (jego zasięg w tym czasie pokazano na ilustracji 1) ${ }^{2}$. W opracowaniach na temat historii Gdańska nie poświęcano zbyt wiele uwagi ani jego historii, ani historii miejsca, w którym się znajdował. Nieliczne zachowane źródła pisane dotyczące wczesnego okresu zagospodarowania obszaru Osieka w niewielkim stopniu zawierają bowiem informacje na temat zajmowanej przez niego przestrzeni. Są one także na tyle ogólnikowe, że badacze interpretują je w bardzo różny sposób. Wynika to $\mathrm{w}$ dużej mierze $\mathrm{z}$ trudności $\mathrm{z}$ odtworzeniem układu topograficznego przedpola zamkowego w XIV w. W artykule chciałabym przedstawić swoje badania na temat warunków osadniczych w tym rejonie oraz na temat jego rozwoju przestrzennego na początku XV w.

\footnotetext{
${ }^{1}$ Erich KeYser, Die Baugeschichte der Stadt Danzig, Köln-Wien 1978, s. 225.

${ }^{2} \mathrm{~W}$ połowie XVI w. jego granica przebiegała na północ od „starego” kanału Raduni biegnącego grzbietem wyniesienia (z ul. Katarzynki i nieistniejącą dziś ul. Podzamcze), od ul. Małe Mniszki (do 1449 r. granicą była ul. Profesorska przy placu kościoła św. Katarzyny) po kanał Raduni biegnący równolegle do zachodnich fos dawnego zamku krzyżackiego (okolice ul. Tartacznej). Jego północną granicę tworzyły: linia biegnąca po krawędzi placu klasztoru św. Brygidy, dalej linia wyznaczająca granice sąsiedzkie nieruchomości przy ul. Mniszki 2/Nonnenhof 5 oraz Stolarskiej 45/46 i 25/26, a następnie ul. Hinter Adlers Brauhaus, Osiek i kanał Raduni. Z czasem jako Osiek zaczęto również określać teren objęty ulicami Stajenną, Rybaki Dolne, Stare Domki i Osiek. Znajdujące się tu nieruchomości odnotowywano od końca XV w. aż do początku XIX w. w księdze gruntowej Starego Miasta. Zob. E. Keyser, Die Baugeschichte, s. 222-223, 230; Archiwum Państwowe w Gdańsku (dalej cyt. APG), sygn. $300 \mathrm{MP} / 2$; sygn. 300, 32/24; sygn. 300, 32/28.
} 


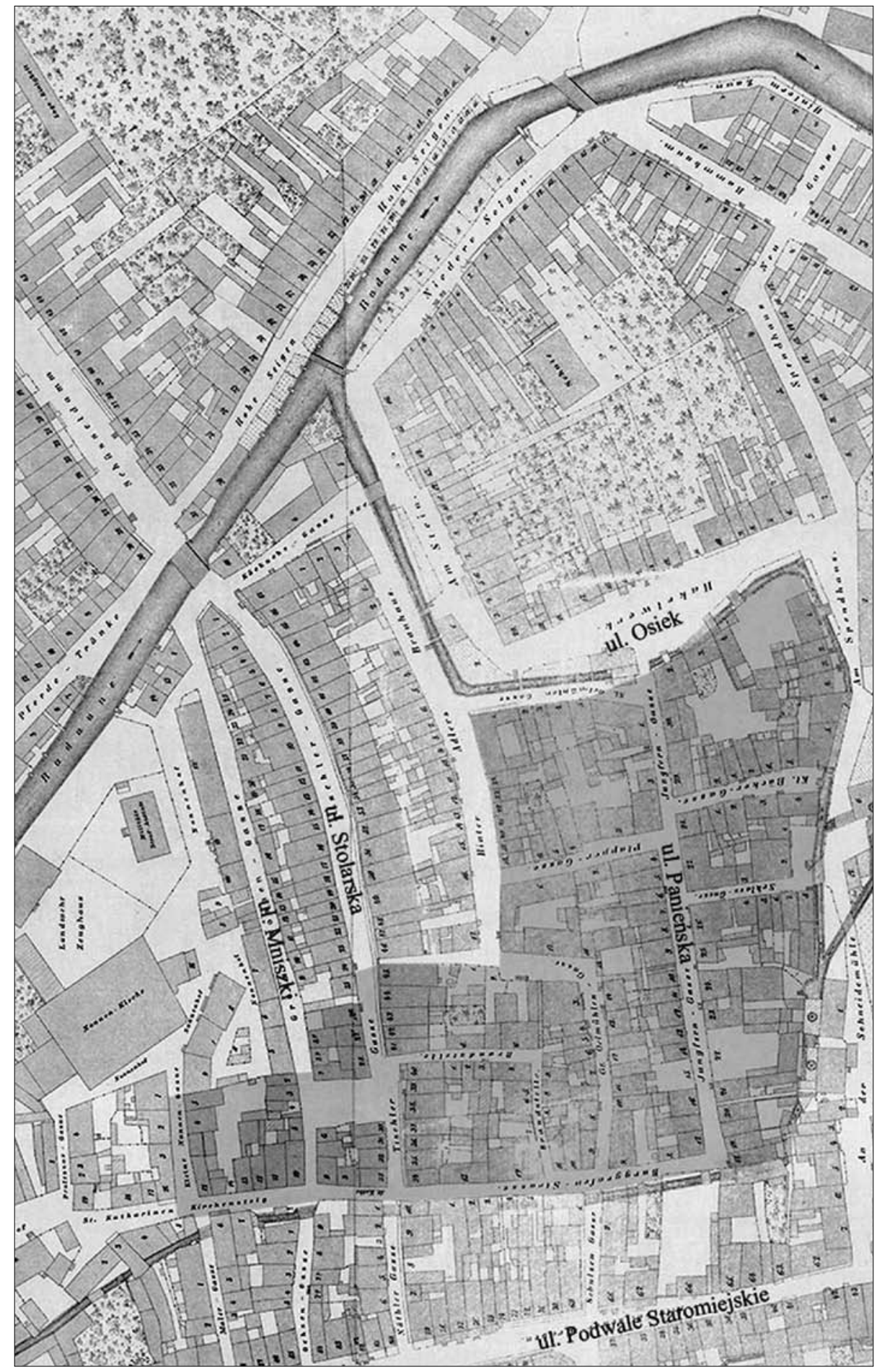

Il. 1. Zasięg Osieka w drugiej połowie XVI w. Opracowanie autorki.

W W W.zapiskih istoryczne.pl 


\section{WARUNKI NATURALNE}

Podczas prac archeologicznych prowadzonych na przełomie lat czterdziestych i pięćdziesiątych XX w. na położonym na wschód od kościoła św. Katarzyny obszarze Starego Miasta stwierdzono, że „od okolic kościoła św. Katarzyny aż do wschodniego końca ul. Grodzkiej ciągnie się grzbiet lekkiego, podłużnego wzniesienia”. Wzniesienie to opadało w kierunku wschodnim. Podsumowując wyniki badań sondażowych przy ul. Wielkie Mniszki, Brygidki i Osiek, Janina Kamińska napisała, że „zalegają tu na samym wierzchu warstwy mułu grubości $126 \mathrm{~cm}$; jest to wynikiem akumulacji wolno płynących wód, zapewne nie tylko tych, które płynęly bezpośrednio od zachodu z Wyżyny Kaszubskiej, ale też płynących z południa wód Motławy"3. Jej spostrzeżenia potwierdziły także wyniki późniejszych badań4. Kilka lat później hipotetyczny przebieg tego cieku pokazał Andrzej Zbierski na planie słowiańskiego osadnictwa wczesnośredniowiecznego z X-XIII w. ${ }^{5}$ Podczas wykonywania planu wykorzystał wyniki badań archeologicznych oraz ustaleń Stanisława Mielczarskiego.

Stanisław Mielczarski zwrócił uwagę na fakt przemieszczania się koryta Wisły w drugiej połowie XIV w. ${ }^{6}$ Uważał, że w wyniku powodzi w 1371 r. Wisła, płynąca

${ }^{3}$ Konrad JAżDżEwski, Ogólne wyniki badań archeologicznych w Gdańsku w latach 1948-1952, Studia Wczesnośredniowieczne, t. 3, Warszawa-Wrocław 1955, s. 139; Janina KamiŃsKa, Metody badań archeologicznych $w$ Gdańsku, ibid., s. 159-161, 163. Przy ul. Osiek calec znajdował się na głębokości od 83 do $135 \mathrm{~cm}$ poniżej poziomu morza, podczas gdy przy kościele św. Katarzyny zalegał już na wysokości około $130 \mathrm{~cm}$ n.p.m. Nisko położone warstwy calcowe obejmowały siny muł (o grubości około $30 \mathrm{~cm}$ w dwóch pierwszych odwiertach, 120 - w trzecim), a pod nim siny piasek - przy ul. Brygidki zawierający zwapniałe resztki muszelek.

${ }^{4} \mathrm{~W}$ badaniach archeologicznych prowadzonych na stanowisku 4, na wschód od ul. Tartacznej odnaleziono pozostałości palowania interpretowane jako resztki umocnień portowych nad lewym, bocznym ramieniem Motławy, zob. Andrzej ZBierski, Port gdański na tle miasta w X-XIII w., Gdańsk 1964, s. 163. Ślady tego samego lub innego cieku odsłonięto także w wykopach między ul. Tartaczną a Panieńską, przy Panieńskiej i przy Sierocej, zob. Zbigniew Misıuk, Wstępne wyniki badań archeologicznych prowadzonych pomiędzy ulicami Tartaczna i Panieńską w Gdańsku przez Fundację Ochrony Zabytków w latach 2008-2010, Pomorania Antiqua, t. 24: 2012, s. 3. Rekonstrukcja przebiegu cieku, którego ślady stwierdzono $\mathrm{w}$ trakcie prac, została przez autora przedstawiona na ilustracji 1. Lidia GRZESZKiewiCz-KotLEwSKA, „Opracowanie wyników badań archeologicznych przy ul. Panieńskiej 3a w Gdańsku w 2007 roku (wykopy I-III)”, Torun 2008 (mps), bez pag; Agnieszka RutA, „Badania ratownicze na stanowisku przy ul. Sierocej. Badania 1998, SAZ 0255/0105/01”, Gdańsk 2002 (mps), bez pag. (archiwum Muzeum Archeologicznego w Gdańsku).

${ }^{5}$ Andrzej ZвIERsкi, Metody badań nad rozplanowaniem wczesnośredniowiecznego Gdańska, Rocznik Gdański (dalej cyt. RG), t. 19/20: 1960-1961, po s. 304. Na planie tym po raz pierwszy pokazał ciek wypływający ze zboczy Góry Gradowej o nazwie Belestruna. Stanowisko to można podać w wątpliwość, gdyż do tej pory nie odnaleziono śladów jakiegokolwiek cieku przecinającego wyniesioną zachodnią część Starego Miasta. Jak wykazał Zbigniew Misiuk, nie może być tak identyfikowany, gdyż miał on przepływać w sąsiedztwie dóbr cysterskich, a takich w rejonie Starego Miasta i Osieka nie było, zob. Zbigniew Misıuk, „Wstępne wyniki badań archeologicznych prowadzonych na obszarze protomiasta gdańskiego pomiędzy dzisiejszymi ulicami Tartaczną i Panieńską w Gdańsku w latach 2008-2010", [s.l., s.a.] (mps), s. 2.

${ }^{6}$ Stanisław Mielczarski, Gdańsk - Młode Miasto (Jungstadt), RG, t. 19/20: 1960-1961, s. 273 -291. Stanowisko S. Mielczarskiego przyjął także: Błażej ŚLIWIŃski, Pomorze Wschodnie w okresie 
wcześniej pod zamkiem - mniej więcej w linii dawnych fos Starego Miasta - odsunęła się od niego na swoją obecną pozycję, a masy naniesionego wówczas mułu i piasku umożliwiły założenie Młodego Miasta na wschód od Starego Miasta. Choć nie zgadzam się z przedstawionymi przez badacza wnioskami na temat tej lokalizacji Młodego Miasta, za niezwykle cenne uważam zwrócenie przez niego uwagi na zmiany, jakie zachodziły w układzie hydrograficznym tego rejonu w średniowieczu, niezależnie od tego, czy miało to być efektem jednorazowej powodzi, czy powolnych zmian.

Dzięki wynikom najnowszych badań archeologicznych dysponujemy dziś wieloma nowymi informacjami na temat warunków naturalnych i czternastowiecznej topografii wschodniej części Starego Miasta i Osieka ${ }^{7}$ Poszerzają one wiedzę, którą można wynieść $\mathrm{z}$ analizy najstarszych materiałów kartograficznych dotyczących Gdańska, pochodzących z pierwszych lat XVII w.: aksonometrycznego szczegółowego planu miasta z około 1600 r. $^{8}$, planu Friedricha Berndta przedstawiającego przedmieścia Gdańska od Motławy po Strzyżę z 1603 r. ${ }^{9}$ oraz planu Gregora Schmera z 1615 r. ${ }^{10}$ i Aegidiusa Dickmanna z 1617 r., charakteryzującego się daleko idącymi uproszczeniami i zniekształceniami ${ }^{11}$. Uzupełnienie tej analizy wynikami uzyskanymi z odwiertów geologicznych oraz z badań archeologicznych przeprowadzonych $\mathrm{w}$ tym rejonie umożliwia podjęcie kolejnej próby opisania tego układu w XIV w. ${ }^{12}$

Podczas prac wykopaliskowych prowadzonych przy ul. Panieńskiej i ul. Sierocej stwierdzono, że przez teren, na którym prowadzono badania, lub w niewielkiej odległości od niego płynął ciek wodny. Ciek przecinał także północno-wschodni narożnik gdańskiej Wiadrowni, opływając od strony północnej wyniesienie, na którym w XI w. powstał gród ${ }^{13}$. Czy była to dawna Wisła, meandrująca na północ od

rząów księcia polskiego Władysława Łokietka w latach 1306-1309, Gdańsk 2003, s. 156. Napisał, że gród opływały „[...] od południa, zachodu i wschodu wody dwu ramion Motławy (lewe ramię obecnie nie istnieje), przy północnej linii grodowych wałów uchodzących do Wisły, płynącej wówczas o $800 \mathrm{~m}$ bliżej miejsca zajmowanego niegdyś przez wyspę grodową niż obecnie”.

${ }^{7}$ Stanowisko nr 2, wykop 8, przy Podwalu Staromiejskim 69-71 (1996 r.); nr 39, wykop 2, róg ul. Heweliusza i Rajskiej (1996 r.); nr 39, wykop 3, róg ul. Heweliusza i Rajskiej (1997/1998 r.); nr 105, wykop 1, ul. Sieroca (1998 r.); nr 39, wykop 4, przy ul. Rajska, Heweliusza (1999-2000); nr 4, wykop 4, pomiędzy ul. Tartaczną a Panieńską (2008-2010); a także przy ul. Panieńskiej (2007, 2014 r.)

${ }^{8}$ Krigsarkivet Stokholm, Nr 0406:25:044:013.

${ }^{9}$ APG, sygn. 300MP/511. Na planie nie przedstawiono obszaru miasta.

${ }^{10}$ Geheimes Staatsarchiv Preußischer Kulturbesitz Berlin-Dahlem (dalej cyt. GStA PK), XI. Hauptabteilung (dalej cyt. HA), AKS Rolle 30L. Także na tym planie nie przedstawiono układu obszaru miasta.

${ }^{11}$ Paul Simson, Geschichte der Stadt Danzig bis 1626, Bd. 2: 1517-1626, Danzig 1918, Beilage: Danzig zu Anfang des 17. Jahrhunderts. Informacji na temat terenów wokół miasta dostarcza także plan z około 1620 r., zob. Krigsarkivet Stokholm, Nr 0406:25:044:001. Plan ten zawiera jednak szereg nieścisłości.

${ }^{12}$ Atlas geologiczno-inżynierski aglomeracji trójmiejskiej Gdańsk-Sopot-Gdynia, kierownictwo Zespołu: Zbigniew Frankowski, Joanna Zachowicz, Gdańsk-Warszawa 2007.

${ }^{13}$ Badania prowadzone były w latach 2011-2012. Na podstawie badań nie można było określić, do kiedy istniał, a także skąd i dokąd płynął. Pozostała po nim warstwa ciemnoszarego namułu zarówno u zbiegu ulic Panieńskiej i Osiek, jak i w rejonie ulic Piekary Wielkie i Mała na Wiadrowni. Charakter osadów wskazuje na to, że był to ciek wolno płynący. 
grodu - trudno jednoznacznie stwierdzić. We wczesnym średniowieczu nie było to jej główne koryto. Na tym dolnym odcinku rzeka płynęła i płynie na poziomie zbliżonym do poziomu morza; jej wody uchodzą do morza nie na skutek naturalnego obniżania się terenu, lecz na skutek naporu spływającej rzeką wody. Stąd tak wiele łach w pobliżu jej ujścia do morza, z których do dziś przetrwało kilka, w tym dwie w bezpośrednim sąsiedztwie miasta - tzw. Rozawójka i Łacha Bosmańska. Niewykluczone też, że zaginiony dziś ciek był jednym z ramion również wolno płynącej Motławy, która jeszcze we wczesnym średniowieczu mogła uchodzić do Wisły kilku odnogami: zachodnią - odcinającą wyniesienie grodu od stałego lądu ${ }^{14}$, środkową - wydzielającą wyspę Brabank i wschodnią - o przebiegu zbliżonym do dzisiejszego jej koryta. Dopiero z czasem, przypuszczalnie na skutek odsunięcia się głównego koryta Wisły na północny wschód i częściowego zasypania lub zamulenia zachodniej odnogi Motławy (w linii późniejszej zachodniej fosy zamkowej), mogło dojść do wzrostu znaczenia obu pozostałych odnóg. Być może na skutek tych zmian wyspa grodowa zaczęła się stopniowo powiększać, dzięki czemu doszło do poszerzenia przedpola zamkowego od strony północno-wschodniej.

Zasięg nadrzecznych mokradeł, utrudniających osadnictwo jeszcze w XIV w., można w przybliżeniu określić, analizując ukształtowanie terenu odnotowane przez dziewiętnastowiecznych geodetów. Na planie z 1884 r. odnotowano rzędne gruntu z zasobów różnych urzędów ${ }^{15}$. Przyjmuje się, że granicę okresowych powodzi wyznacza poziom $3 \mathrm{~m}$ n.p.m. Poniżej tej warstwicy znajdował się obszar położony na wschód od ul. Stolarskiej i Łagiewniki oraz na północ od klasztoru brygidek, opadający w kierunku Wisły ${ }^{16}$. Podmokły obszar sięgał w średniowieczu aż po rejon ul. Rajskiej. Jak wskazują wyniki badań archeologicznych, były to tereny zajęte kiedyś przez stojące wody, które ulegały stopniowemu osuszeniu ${ }^{17}$. $\mathrm{Na}$ krawędzi obniżenia, w rejonie nieistniejącej dziś ulicy Kumstgasse, odsłonięto wczesnośredniowieczną osadę i pochylnie służące zapewne do wyciągania łodzi

${ }^{14}$ Odnogę tę, lub rejon ujścia Potoku Siedleckiego do Motławy, uchwycono w badaniach archeologicznych na stanowisku IV w latach pięćdziesiątych XX w., zob. A. ZBIERski, Port gdański, s. 71. Odsłonięty calec był zbliżony do calca stwierdzonego na Osieku. Miał także spąg na zbliżonej wysokości - $70 \mathrm{~cm}$ p.p.m.

${ }^{15}$ APG, sygn. $300 \mathrm{MP} / 846$.

${ }^{16}$ Jak wskazuje ukształtowanie terenu Starego Miasta i Osieka, jeszcze w końcu XIX w. warstwica $3 \mathrm{~m}$ biegła wokół wyniesienia dawnego grodu i dalej na zachód, obejmując rejon ul. Sierocej, północną części ul. Panieńskiej, Stajenną i Osiek, północną część klasztoru św. Brygidy i ul. Wodopój. Dalej biegła na północ wzdłuż ul. Łagiewniki. Zob. także: Walter GeısLer, Die Großstadtsiedlung Danzig, Danzig 1918, Karte III. Publikowany przez niego plan hipsometryczny Gdańska wykorzystywany był przez innych badaczy. Pokazane na nim warstwice pokazują wysokość od 1/2 do $1 \mathrm{~m}$ wyższą, niż wynika to z rzędnych odnotowanych na planie z 1884 r. Inny jest też przebieg warstwicy oznaczającej poziom $3 \mathrm{~m}$ n.p.m.

${ }^{17} \mathrm{O}$ ile calec w rejonie ul. Rajskiej tworzyły piaski, o tyle nieco dalej na wschód - torf, a pod nim glejone piaski. Jest to informacja ustna od archeologów prowadzących badania na stanowisku „Rajska” Roberta Krzywdzińskiego i Macieja Szyszki, którym dziękuję za życzliwość. Torfy występowały też po wschodniej stronie ul. Łagiewniki, między ul. Rybaki Górne a Heweliusza (również informacja ustna od Aleksandra Kwapińskiego prowadzącego badania na tym stanowisku). 


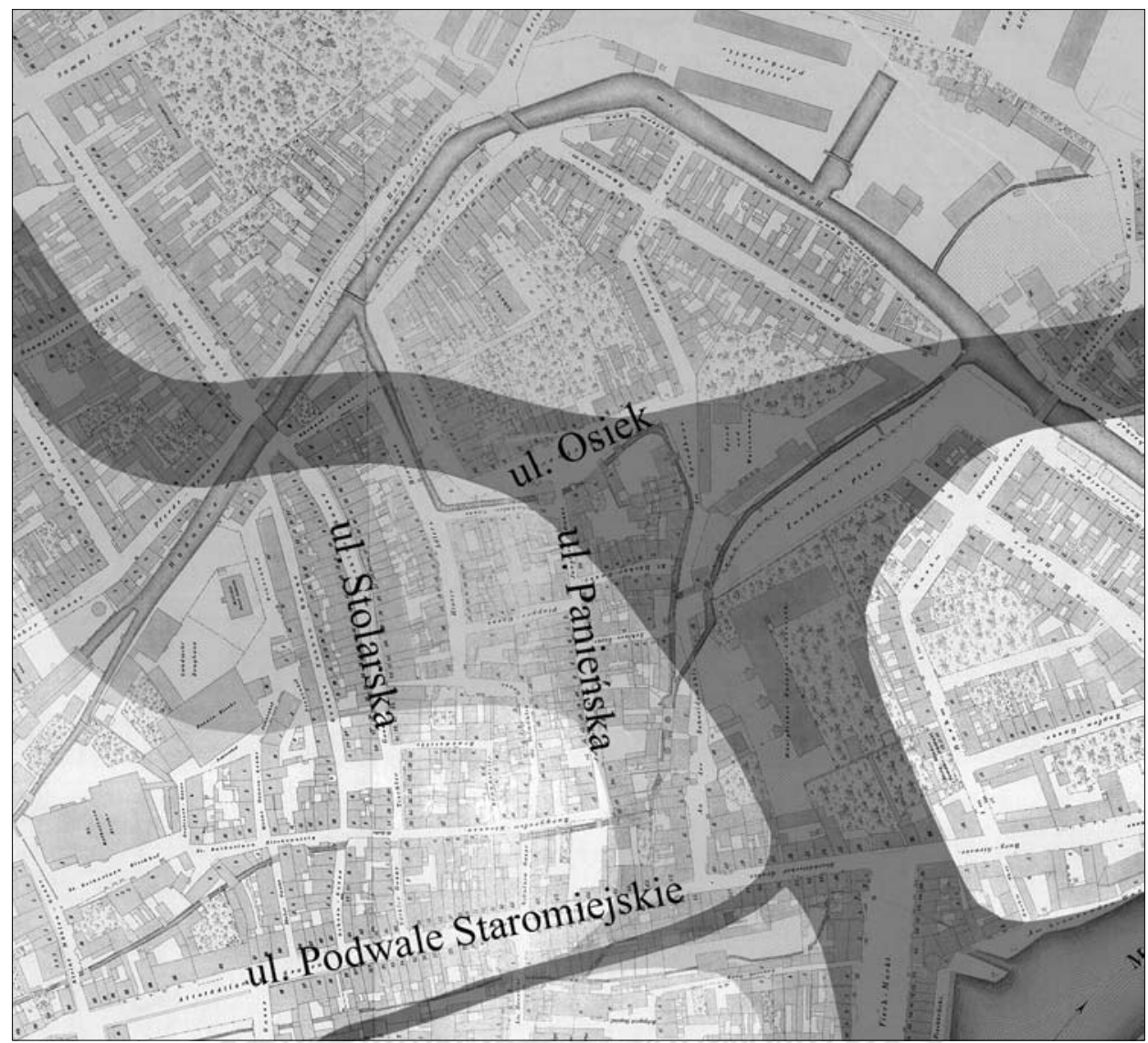

Il. 2. Topografia okolic Osieka w końcu XIII w. Jaśniejszym kolorem oznaczono tereny podmokłe. Opracowanie autorki.

na brzeg jakiegoś nieznanego cieku, którym można było się dostać do większej rzeki - Motławy lub Wisły ${ }^{18}$. Być może był nim ciek, którego istnienie stwierdzono przy ul. Piekary Wielkie, Panieńskiej lub Tartacznej ${ }^{19}$. Odnalezienie dużej liczby haczyków i spławików w położonym w okolicach ul. Tartacznej wczesnośredniowiecznym siedlisku pozwala przypuszczać, że także tu znajdowała się osada, której ludność w jakiejś części zajmowała się rybołówstwem.

Zarówno A. Zbierski, jak i Z. Misiuk uważali, że był to ciek mający swoje źródła na zboczach Góry Gradowej ${ }^{20}$. Skłonna jestem jednak przypuszczać, że ciek, na który natrafiono, nie spływał z wysoczyzny, lecz był kolejną dawno zaginioną łachą wiślaną opływającą wyspę grodową od północy lub dawną zachodnią odnogą Motławy, uchodzącą do Wisły w rejonie późniejszej stoczni królewskiej (il. 2).

${ }^{18}$ Według M. Szyszki wskazywały na to przecinające pochylnie rowki, które mogły być przeznaczone pod przesuwanie stępki łodzi.

${ }^{19}$ L. GrZeszKiewicz-KotlewsKa, op.cit.

${ }^{20}$ Zob. przyp. 5. 


\section{ZAŁOŻENIE OSIEKA}

Najwcześniejszym dokumentem odnoszącym się - jak się powszechnie uważa - do mieszkańców Osieka jest dokument z 1312 r. mówiący o potwierdzeniu prawa do połowu bursztynu i ryb nadanego im przez książąt pomorskich, wydanego przez wielkiego mistrza krzyżackiego Karla von Trier ${ }^{21}$. O tym, że dotyczył mieszkańców Osieka, świadczy tytuł dodany dokumentowi w XV w. W dokumencie z 1402 r. są oni opisywani zarówno jako Polacy, jak i rybacy ${ }^{22}$. Według Ericha Keysera początek Osiekowi dało przesiedlenie mieszkańców słowiańskiej osady przygrodowej między 1308 a 1310 r. w pobliże zamku, o czym w swojej kronice informować miał Simon Grunau: „Man solt bawen under das schloss und sie bawtten mit unwillen in das gesumpe ein pflugewende vom schloss und heisst heute die Altstadt" ${ }^{23}$. E. Keyser zgadzał się z opinią Rudolfa Griesera wskazującą, że takie działanie, mające na celu kontrolę obcej narodowo ludności przez osadzenie jej w siedlisku otoczonym kolczastymi zasiekami lub płotami, było krzyżackim zwyczajem²4.

Zbliżoną opinię na temat początków Osieka przedstawił Marian Biskup ${ }^{25}$. Natomiast Theodor Hirsch, Gustav Köhler, Paul Simson i Marian Małuszyński byli zdania, że była to osada jeszcze słowiańska, której potwierdzono posiadane przywileje po zajęciu Gdańska przez Krzyżaków ${ }^{26}$.

Nie ma także jednomyślności co do położenia czternastowiecznego Osieka. Jego nazwa (niem. Hakelwerk) jest najczęściej wywodzona od określenia osady otoczonej kolczastymi zasiekami ${ }^{27}$. Według Walthera Stephana i E. Keysera miała zajmować obszar otoczony w późniejszym czasie wąskimi kanałami, odnogami łą-

${ }^{21}$ Paul Simson, Geschichte der Stadt Danzig bis 1626, Bd. 4: Urkunden bis 1626, Danzig 1918, Nr. 68. Dokument zatytułowany został w XV w. „Der hachelwerker vor dem huse hantveste” i stąd wiadomo, że jego treść wiąże się z Osiekiem. W źródle nazwy tej się nie wymienia. Wzmiankowani są w nim „Piscatoribus nostris Gdaniensibus”. Dokument zachował się w piętnastowiecznym odpisie w Archiwum Państwowym w Gdańsku.

${ }^{22}$ P. Simson, op.cit., Bd. 4, Nr. 117. Jako Polacy i Prusowie określeni są natomiast w dokumencie z 1348 r., zob. ibid., Nr. 85.

${ }^{23}$ E. Keyser, Die Baugeschichte, s. 107. E. Keyser uważał, że gdańskie miasto książęce znajdowało się na terenie późniejszego Głównego Miasta; słowa dokumentu stanowiły dla niego dowód na późne założenie Starego Miasta.

${ }^{24}$ Ibid., s. 108, 221.

${ }^{25}$ Marian Biskup, Układ przestrzenny gdańskiego zespołu miejskiego, [in:] Historia Gdańska, red. Edmund Cieślak, t. 1: Do roku 1454, Gdańsk 1978, s. 373. Jerzy Stankiewicz nie zajmował jednoznacznego stanowiska co do początków Osieka. Nie wykluczał, że istniał on już w czasach pomorskich, zob. Jerzy StAnkiewicz, Bohdan Szermer, Gdańsk. Rozwój urbanistyczny i architektoniczny oraz powstanie zespołu Gdańsk-Sopot-Gdynia, Warszawa 1959, s. 32.

${ }^{26}$ Theodor Hirsch, Danzigs Handels- und Gewerbegeschichte unter der Herrschaft des Deutschen Ordens, Leipzig 1858, s. 8; Gustav KöHLER, Geschichte der Festungen Danzig und Wichselmünde bis zum Jahre 1814, Breslau 1893, s. 25-26; Paul Simson, Geschichte der Stadt Danzig bis 1626, Bd. 1: Von den Anfängen bis 1517, Danzig 1913, s. 48; Marian MaŁuszyński, Zabór Pomorza przez Krzyżaków (1308-1309), RG, t. 7-8: 1933-1934, s. 56.

${ }^{27}$ E. Keyser, Die Baugeschichte, s. 108; Marian BISkup, Kształtowanie się miejskiego zespołu osadniczego, [in:] Historia Gdańska, t. 1, s. 350. M. Małuszyński tłumaczył tę nazwę jako „zasiek, pierwotne umocnienie z drzew ściętych", zob. idem, op.cit., s. 56. 
czącymi starszy kanał Raduni z późniejszym. A więc zawierać się miała pomiędzy ulicami Olejarnią (Ölmühlengasse) - od zachodu, Osiek (Hakelwerk) - od północy, Sierocą (Am Spendhaus), Tartaczną (Schneidemühle) - od wschodu i nieistniejącym dziś załamaniem ul. Olejarnia (Ölmühlengasse) od południa. Główną ulicą Osieka miała być ul. Panieńska (Jungferngasse). E. Keyser uważał, że w miejscu kanałów mogły wcześniej istnieć suche rowy opasujące siedlisko ${ }^{28}$. Jego poglądy na temat zasięgu Osieka w XIV w. zostały powtórzone przez M. Biskupa i przedstawione na planie autorstwa Ryszarda Massalskiego i Jerzego Stankiewicza ${ }^{29}$. Podobnego zdania byli wcześniejsi badacze. Według Augusta Bertlinga około 1382 r. Osiek rozciągał się od południowego rowu wymienionego przez E. Keysera po kwartał nazywany w nowożytności Osiekiem, tj. po ulicę Rybaki Dolne (Nieder Seigen $)^{30}$. G. Köhler widział czternastowieczny Osiek na obszarze między przedłużeniem nieistniejącej dziś ulicy Brandstelle a ul. Osiek oraz ul. Browarną a małym kanałem Raduni, z gruntami, które miały się rozciągać od placu kościoła św. Katarzyny (miał należeć do nich plac nadany brygidkom ${ }^{31}$ ) po ul. Panieńską i na północ aż po późniejsze Młode Miasto $^{32}$. T. Hirsch nie precyzował jego zasięgu, pisząc jedynie, że leżał na zachód od zamkü3.

Odkrycie śladów zniszczonej osady rybackiej między ul. Rajską a Kumstgasse powoduje, że ponownego rozważenia wymaga wzmianka o przeniesieniu ludności na przedpole zamkowe. W 1308 r. zarówno miasto lubeckie (o nieznanej dotychczas lokalizacji), jak i osada zostały zniszczone, a ich mieszkańcy zmuszeni do opuszczenia swoich domostw. Ściany domów osady zostały rozebrane, a zagłębione w gruncie elementy konstrukcyjne drewnianych domów zostały wycięte ponad ziemią, tak jakby miały być przeznaczone do powtórnego użycia. Nie można więc wykluczyć, że ludność wysiedlona z tej osady mogła dać początek Osiekowi. Być może do rybaków tej właśnie osady oraz rybaków zamieszkujących na podgrodziu odnosi się dokument z 1301 r., w którym napisano „qui tandem cum aliis militibus et hominibus ac consilibus et civibus atque piscatoribus civitatis et castri Gdanensis" ${ }^{34}$. Ewentualne

${ }^{28}$ E. Keyser, Die Baugeschichte, s. 222.

${ }^{29}$ M. Biskup, Układ przestrzenny, s. 374-375; idem, Przemiany przestrzenne $i$ demograficzne, [in:] Historia Gdańska, t. 1, s. 498.

${ }^{30}$ Biblioteka Gdańska PAN, sygn. C I 644.

${ }^{31}$ P. Simson, op.cit., Bd. 4, Nr. 110 z 1394 r. W dokumencie tym znajduje się wyraźne stwierdzenie, że plac, który zajmują brygidki i na którym mogą zbudować swoją kaplicę, znajduje się na Starym Mieście.

${ }^{32}$ G. KöHLER, op.cit., Tafel VIII. G. Köhler uważał, że tzw. nowa grobla prowadząca na Młode Miasto została poprowadzona przez grunty należące do Osieka, zob. ibid., s. 26, 32. Na ten temat także: P. Simson, op.cit., Bd. 1, s. 94. Pogląd ten stoi w sprzeczności z zasięgiem obszaru Starego Miasta odnotowanym w jego księdze gruntowej z 1400 r., zob. Josef Kaufmann, Studien zur Geschichte der Altstadt Danzig, Zeitschrift des Westpreussischen Geschichtsvereins (dalej cyt. ZWG), H. 55: 1913, s. 118.

${ }^{33}$ T. Hirsch, op.cit., s. 8.

${ }^{34}$ P. Simson, op.cit., Bd. 4, Nr. 59. Zofia Hołowińska przypuszczała, że rybacy wymienieni w dokumencie mogli być mieszkańcami grodu, zob. eadem, Dzielnica rzemieślnicza z XIII i XIV wieku w Gdańsku (stanowisko 2), Gdańsk Wczesnośredniowieczny, t. 6: 1967, s. 237. 
przeniesienie słowiańskich rybaków dawnego miasta oraz rybaków z podgrodzia na przedpole zamkowe $\mathrm{z}$ jednej strony gwarantowało zachowanie nad nimi kontroli (o czym pisali R. Grieser i E. Keyser), z drugiej umożliwiało racjonalne wykorzystanie opuszczonych przez nich gruntów.

Powstanie Osieka wydaje się bardzo silnie związane z istniejącym na początku XIV w., opisanym powyżej układem topograficznym tej części miasta i dalekosiężnymi planami Zakonu w stosunku do nowo zdobytych terenów. Po zajęciu Gdańska Krzyżacy dążyli zapewne do stworzenia warunków umożliwiających maksymalne wykorzystanie zdobytego terytorium. Usunięcie ufortyfikowanego miasta z drogi prowadzącej na przyszły zamek zapewniało bezpieczny do niego dostęp. Być może też już wówczas przewidywano docelowy zasięg Starego Miasta, które z czasem objęło również obszar opuszczony przez mieszkańców rybackiej osady. Powodem tych zmian mogło być także zamulanie się cieku wodnego, którym do niej dopływano.

\section{TOPOGRAFIA CZTERNASTOWIECZNEGO OSIEKA}

Na podstawie źródeł pisanych możliwe jest określenie obszaru dopiero szesnastowiecznego Osieka. Jego centrum z ratuszem znajdowało się wówczas przy ul. Stolarskiej ${ }^{35}$. Co do tego, jaki obszar zajmował w drugiej połowie XIV w., nie ma zgodności. Do tej pory nie dysponujemy bowiem wynikami badań, które pozwoliłyby na jednoznaczne określenie jego pierwotnego obszaru. Nie odnaleziono śladów czternastowiecznego Osieka na obszarze wskazywanym przez E. Keysera jako jego centrum. Wyniki badań archeologicznych prowadzonych między ul. Panieńską a Olejarnią w dwóch etapach: w roku 2007 i 2014 (objęły one ponad 1/5 ewentualnego centrum Osieka) wskazują, że w tym rejonie nie było osadnictwa wcześniejszego niż późne lata czterdzieste XIV w. ${ }^{36}$ Jeszcze w tym czasie był to teren bardzo podmokły, dopiero meliorowany, zapewne w celu przystosowania pod zasiedlenie (il. 3).

W rejonie północnego zakończenia ul. Panieńskiej, a także przy ul. Sierocej znajdowało się obniżenie terenu, noszące ślady okresowego zalewania ${ }^{37}$. Odnaleziono tu dwa dobrze zachowane więcierze, co wskazuje, że jeszcze na początku XIV w. niedaleko znajdował się jakiś ciek wodny, jak wynika z osadów - okresowo dość wartko płynący ${ }^{38}$. W pobliżu, na południe od terenu wskazywanego przez E. Keysera jako centrum Osieka, odsłonięto osadnictwo wczesnośredniowieczne w postaci wielu warstw drewnianych domów i zabudowań gospodarczych. Nie była to jednak zabudowa osady stricte rybackiej. Na podstawie znalezisk nie można było jednoznacznie określić, czym zajmowali się jej mieszkańcy. W tym miejscu, na wschod-

${ }^{35}$ APG, sygn. 300, 32/24, k. 6v, 33r.

${ }^{36}$ L. Grzeszkiewicz-KotlewsKa, op.cit. Choć uzyskana data dendro z jednej z belek podwaliny najstarszego domu to 1318 r., pozostałe odnoszą się do lat czterdziestych XIV w.; jedna z nich to nawet $1354 \mathrm{r}$.

${ }^{37}$ L. Grzeszkiewicz-Kotlewska, op.cit.; A. Ruta, op.cit.

${ }^{38}$ L. GrzeszKiewicz-Kotlewska, op.cit. 


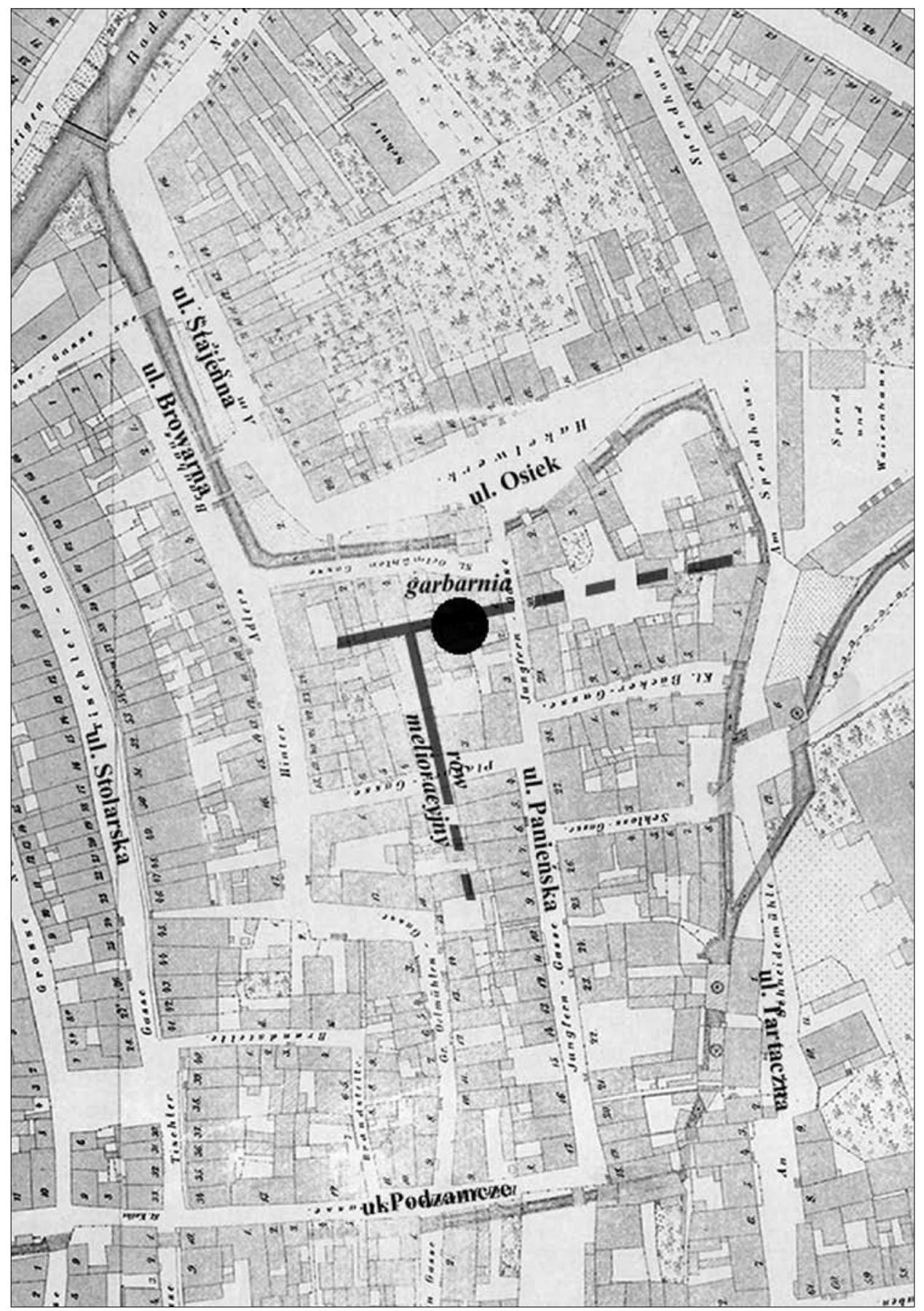

Il. 3. Usytuowanie rowów oraz garbarni odsłoniętych w trakcie badań archeologicznych przy ul. Panieńskiej. Opracowanie autorki na podstawie sprawozdania z badań Lidii Grzeszkiewicz-Kotlewskiej. 
niej krawędzi grzbietu biegnącego od strony kościoła św. Katarzyny, osadnictwo istniało nieprzerwanie od końca XII w. po pierwsze dwie dekady XIV w., kiedy rozebrano znajdujące się tu domy ${ }^{39}$. Natomiast trwało ono dalej na obszarze położonym na zachód - od okolic Podwala Staromiejskiego co najmniej po ul. Katarzynki i dawną ul. Podzamcze. Zofia Hołowińska i Andrzej Zbierski sądzili, że sięgało aż po rejon nieistniejącego północnego odcinka ul. Olejarnia i klasztor brygidek ${ }^{40}$. Do tej pory ślady osadnictwa wczesnośredniowiecznego stwierdzono jednakże tylko w pasie nieprzekraczającym ul. Katarzynki i Podzamcze ${ }^{41}$.

W latach trzydziestych XIV w. omawiany obszar osadnictwa został przecięty przez kanał Raduni, co wpłynęło na zmianę orientacji wznoszonych budynków, do tej pory skierowanych ku wczesnośredniowiecznemu traktowi komunikacyjnemu, biegnącemu prawie równolegle do późniejszego Podwala Staromiejskiego. Miał on dostarczać siły napędowej krzyżackim urządzeniom gospodarczym i wodę do fos zamkowych. Poprowadzono go w linii grzbietu wyniesienia, w sposób naturalny stopniowo opadającego w kierunku zamku². Dostarczał wodę do łaźni krzyżackiej i dalej biegł przy krawędzi gospodarczego podzamcza, poruszając koła tartaku. Uważa się, że po wpadnięciu do zewnętrznej fosy zamkowej i minięciu północnej baszty bramnej podzamcza znajdował ujście w późniejszym Kanale Wiadrowników, zapewne bocznym ramieniu Motławy ${ }^{43}$. W 1402 r. istniała już także odnoga kanału uchodząca do nowego Kanału Młyńskiego u wylotu ul. Browarnej (Hinter Adlers Brauhaus). Woda płynęła w niej w kierunku młynówki; najwyższy punkt znajdował się w rejonie tartaku ${ }^{44}$, skąd płynęła dalej po krawędzi nisko położonych łąk ${ }^{45}$. Przypuszczalnie wykopano ją około połowy XIV w., kiedy wykonano nowy Kanał Młyński. Na początku XV w. korzystali z tej odnogi mieszkańcy Osieka płynący łodziami do swoich domów ${ }^{46}$.

Nie można wykluczyć, że osada rybacka założona w drugim dziesięcioleciu XIV w. zajęła obszar położony na północ od już istniejącego osadnictwa, na kra-

${ }^{39}$ Z. Misıuk, Wstępne wyniki, s. 4.

${ }^{40}$ Zofia HoŁowińska, Materialy archeologiczne do badań nad najstarszym Gdańskiem lokacyjnym, Kwartalnik Historii Kultury Materialnej, R. 8: 1960, nr 1, ryc. 1; A. ZBIERsKi, Port gdański, plan 12.

${ }^{41}$ Z. HoŁowiŃsKa, Dzielnica rzemieślnicza, s. 212, 215, 232-233.

${ }^{42}$ Po usunięciu zabudowy w rejonie ul. Tartacznej, przed poprowadzeniem kanału, teren został podwyższony o kilkadziesiąt centymetrów, zapewne z powodu zamierzonej budowy tartaku poniżej tego miejsca, zob. Z. Misıuk, Wstęne wyniki, s. 6.

${ }^{43}$ Nie do końca jasny pozostaje przebieg końcowego fragmentu tego kanału, na odcinku poza tartakiem. Według planów z początku XVII w. nie łączył się on z fosami, lecz przepływał równolegle do ich zachodniego odcinka, by potem połączyć się z kanałem biegnącym wzdłuż ul. Stajennej i Browarnej. Ten przebieg kanału był jednak możliwy dopiero po wykonaniu nowej młynówki w latach pięćdziesiątych XIV w. - nie był więc pierwotnym jego ujściem. Nie można wykluczyć, że początkowo wpływał on bezpośrednio do Wisły na północ od zamku, poza linią fos.

${ }^{44}$ Grunt, przez który przekopano kanał, podniesiono do poziomu 1,9-2,25 m n.p.m., zob. Z. Misıuk, Wstępne wyniki, s. 6.

${ }^{45}$ Calec odsłonięto na poziomie od 0,63-1,3 m p.p.m., zob. L. Grzeszkiewicz-Kotlewska, op.cit.

${ }^{46}$ P. Simson, op.cit., Bd. 4, Nr. 128. 
wędzi meliorowanego obniżenia, obejmując pas terenu przypisywany w późnośredniowiecznej księdze czynszowej i nowożytnej księdze gruntowej Osiekowi ${ }^{47}$. Jak się wydaje, ze względu na kilkudziesięciometrową odległość od kanału, ewentualne osadnictwo tej skrajnej części wyniesienia mogło przetrwać budowę kanału bez większych zmian.

\section{PIĘTNASTOWIECZNY OSIEK}

Pierwszych informacji na temat zasięgu Osieka dostarcza dokument z $1402 \mathrm{r}^{48}$ Stanowi on jeden z serii kilku zachowanych dokumentów dotyczących Starego Miasta i Osieka z ostatnich lat XIV i początku XV w. Ich treść wskazuje na to, że w tym czasie Krzyżacy podjęli szereg decyzji mających zapewne na celu dalekosiężne uporządkowanie obszaru obu tych ośrodków, a także powiązanie ze sobą poszczególnych członów zespołu miejskiego. W 1394 r. wielki mistrz Konrad von Jungingen zezwolił na budowę kaplicy pokutnic w sąsiedztwie kościoła św. Katarzyny ${ }^{49}$. Siedem lat później zadecydowano o odebraniu osieczanom przyległego terenu i przekazaniu im w ramach zamiany innego. Grunt będący przedmiotem transakcji położony był pomiędzy klasztorem brygidek a odnogą małego kanału poprowadzoną wzdłuż ul. Browarnej (Hinter Adlers Brauhaus). Od strony południowej sięgał do późniejszej granicy Osieka - linii przejścia między działkami położonymi przy ul. Stolarskiej (Tischlergasse) 45 i 46 oraz 25 i $26^{50}$. Jego powierzchnia wynosiła 3 sznury $1 / 2$ pręta x 2 sznury bez $2 \frac{1}{2}$ pręta $(131,8$ x 97,2 m). Dzięki tej wymianie Krzyżacy mogli przystąpić do realizacji swoich zamierzeń co do tego i sąsiadującego $\mathrm{z}$ nim obszaru. Z dokumentu wynika, że planowali szybkie zasiedlenie na prawie chełmińskim działek położonych wzdłuż części ulicy biegnącej z Osieka do Młodego Miasta (między „nowym mostem” a Osiekiem). Z nazwy, którą nosiła ta i dalsza jej część poza mostem nad Radunią, można także wnioskować, że zamierzano ją poprowadzić na nasypie jako groblę, dzięki czemu po jej wykonaniu możliwe było przystąpienie do osuszania gruntów położonych od niej na zachód ${ }^{51}$. W tym czasie obszar położony na zachód i południe od Osieka, częściowo także na północ od Kanału Raduni, należał do Starego Miasta ${ }^{52}$.

W zamian za utracony grunt mieszkańcy Osieka otrzymali pod zasiedlenie pewien obszar w sąsiedztwie krzyżackiej garbarni i Osieka oraz działkę określoną jako „Schild”, położoną u ujścia Kanału Raduni do Motławy, na której mogli trzy-

${ }^{47}$ E. Keyser, Die Baugeschichte, s. 515-517; J. Kaufmann, op.cit, s. 118-119.

${ }^{48}$ P. Simson, op.cit., Bd. 4, Nr. 117.

${ }^{49}$ Ibid., Nr. 110. G. Köhler uważał, że było to nadanie na gruntach Osieka, zob. idem, op.cit., s. 26.

${ }^{50}$ E. Keyser, Die Baugeschichte, s. 223.

${ }^{51}$ P. Simson, op.cit., Bd. 4, Nr. 123. Ten odcinek określany był jako „nue tamm”. Jeszcze w $1425 \mathrm{r}$. nazwą „nuwen Thamm” opisywano także ul. Stolarską, zob. ibid., Nr. 128. Z odwiertów geologicznych wiadomo, że zarówno teren położony po zachodniej, jak też po wschodniej jej stronie był bardzo nisko położony. Zob. J. KAMIŃsKA, op.cit., s. 160-161.

${ }^{52}$ Około 1400 r. graniczyło ono z Osiekiem od strony południowej od krawędzi placu kościoła św. Katarzyny po staromiejskie jatki rzeźnicze, zob. J. KaUfmanN, op.cit., s. 118. 
mać łodzie oraz suszyć sieci. Obszar nadania miał się znajdować między Osiekiem a łąkami krzyżackimi otoczonymi groblą i od miejsca określonego „am stege bey dem gerberhove” do rowu rozciągającego się na zapleczu działek przy „nue gasse” (ul. Stolarskiej), czyli wzdłuż dzisiejszej ul. Browarnej. Wskazanie miejsca niezbędnego do uprawiania rybołówstwa zdaje się dowodzić, że odstępując teren położony wzdłuż ul. Stolarskiej, rybacy z Osieka utracili miejsce o podobnej funkcji. Na skutek zamiany powstała sytuacja, w której zmuszeni byli - by dostać się do swoich łodzi - do przechodzenia lub przepływania przez miejsca strzeżone przez Krzyżaków, a więc zapewne w sąsiedztwie zamku. Wskazuje na to uwaga mówiąca o tym, że nie powinni być zatrzymywani przez krzyżackich strażników w drodze do domu. Zachowali dawne prawo do pływania po młynówce, trzymania w niej koszy z rybami po obu stronach i sprzedaży ryb na nabrzeżach. Zgodnie z tradycją był to odcinek Raduni położony tuż poniżej gruntów będących przedmiotem wymiany.

W dokumencie z 1425 r., w którym Krzyżacy oddali w dzierżawę Niclosowi Fronemu i jego spadkobiercom łąkę przy garbarni, napotykamy te same punkty topograficzne opisujące przestrzeń nadania oraz dodatkowe informacje ${ }^{53}$. Okazuje się, że łąka wydzierżawiana Niclosowi Fronemu znajdowała się między krzyżacką garbarnią a młynówką, przy której znajdowała się obsadzana wierzbami grobla obiegająca łąki. Z jego posesji „uff dem nuwen Thamme” na łąki prowadził most nad rowem.

O ile treść obu dokumentów jest jasna, to jednak niezwykle trudno odnieść ją do konkretnej przestrzeni. Czternastowieczna topografia tego rejonu miasta odbiega bowiem znacznie - jak starałam się to wykazać - od dzisiejszej lub możliwej do odtworzenia na podstawie nowożytnych planów miasta. Na żadnym z nich nie można odnaleźć śladów łąk obwiedzionych groblą obsadzaną wierzbami ani garbarni. Znany jest jedynie przebieg kanału prowadzącego od Osieka do młynówki. Nic więc dziwnego, że informacje z dokumentu w bardzo różny sposób przenoszone były w przestrzeń miasta.

Według G. Köhlera, a za nim P. Simsona nowo przyznane grunty miały się rozciągać na wschód od dotychczasowego siedliska aż po łąki i garbarnię, którą sytuowali na krawędzi wału na wprost skrajnej północnej baszty zamkowej nad kanałem Raduni ${ }^{4}$ (il. 4). Obejmowałyby więc teren położony na wschód od ul. Panieńskiej z kwartałem między ul. Osiek a Rybaki Dolne. Trudno stwierdzić, czym kierował się G. Köhler, umieszczając garbarnię w tym właśnie miejscu ${ }^{55}$. Znane były mu późniejsze, pochodzące z początku XVII w. plany miasta i jego przedpola, stąd wiedział, że mniej więcej w linii późniejszej ul. Krosna („Neuer

\footnotetext{
${ }^{53}$ P. Simson, op.cit., Bd. 4, Nr. 123.

${ }^{54}$ G. KöHLER, op.cit., s. 26 i Tafel I, II; P. Simson, op.cit., Bd. 1, s. 112, Beilage: Danzig am Ende der Ordenszeit.

${ }^{55}$ Wskazana przez Köhlera lokalizacja wydaje się niewłaściwa ze względu na przeznaczenie kanału, nad którym się znajdował. Był on bowiem wykorzystywany do transportu bali drewna do tartaku znajdującego się na przedpolu zamkowym. Jego zawężenie byłoby więc niekorzystne ze względów funkcjonalnych, równocześnie koła młyńskie mogłyby być narażone na uszkodzenia. Jeszcze w XVII w. był wykorzystywany w tym celu, zob. APG, sygn. 300R, Bb/26c, s. 105.
} 


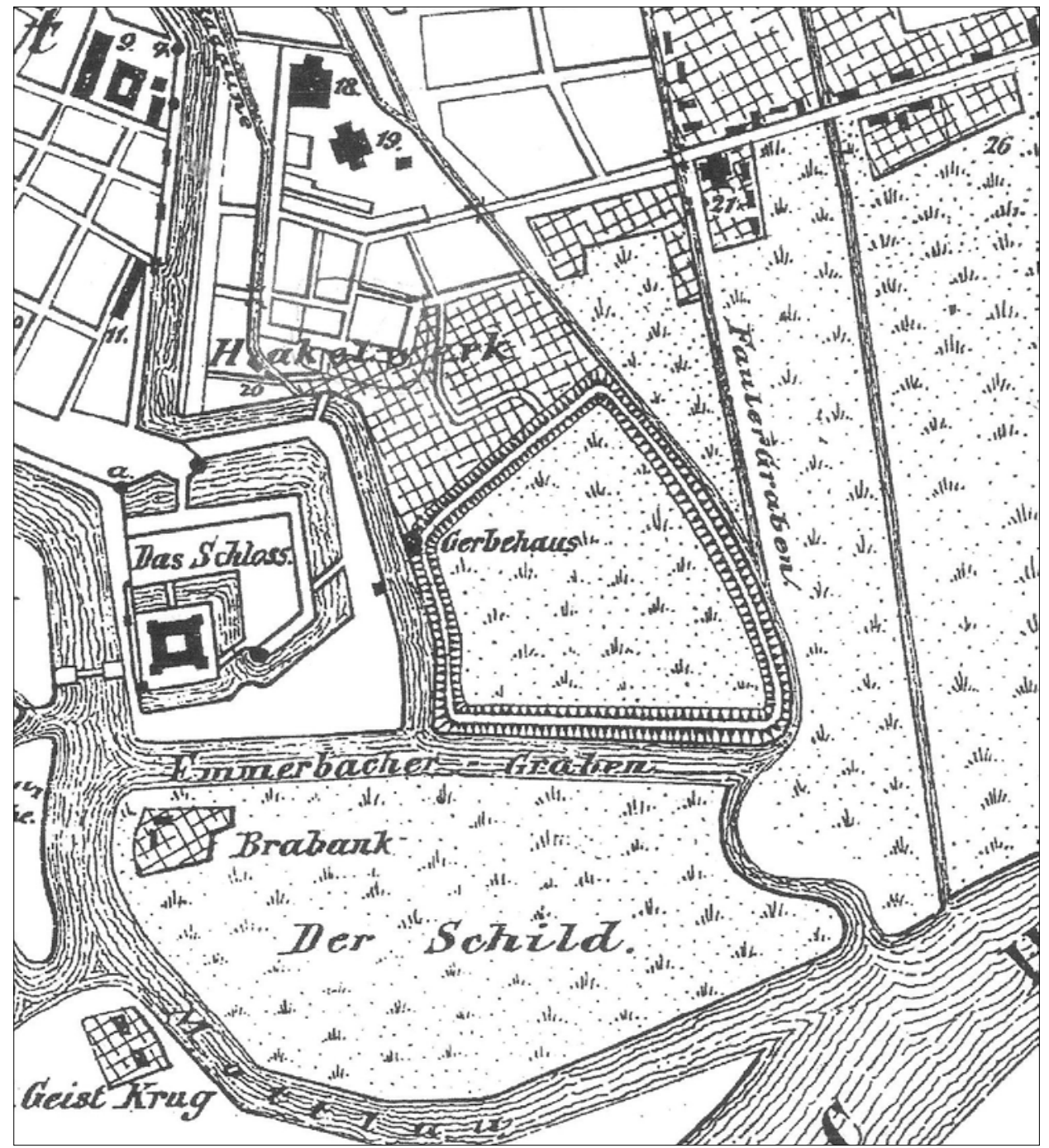

Il. 4. Fragment planszy przedstawiającej Gdańsk w okresie panowania krzyżackiego według: G. KöHLER, Geschichte der Festungen Danzig und Wichselmünde bis zum Jahre 1814, Breslau 1893, Tafel II.

Rammbau”) biegł wał określany na planach jako stary ${ }^{56}$. Uważał zapewne, że stanowi on pozostałość po wymienionej w dokumencie grobli otaczającej krzyża-

${ }^{56}$ W kronice Beyera znajduje się wzmianka z 1518 r. mówiąca o tym, że mieszczanie staromiejscy uzyskali zezwolenie na wykonanie palisady z tyłu „Rampawer Kirchhoff” aż do Raduni. Nie wiadomo, czy dotyczyło to zabezpieczenia wierzchołka wałów, czy też oznacza, że wcześniej w linii wału nie było jakichkolwiek obwarowań, co stawiałoby pod znakiem zapytania koncepcję Köhlera. Zob. Christoph Beyers des ältern Danziger Chronik, hrsg. v. Theodor Hirsch, [in:] Scriptores rerum Prussicarum, Bd. 5, hrsg. v. Theodor Hirsch, Max Toeppen, Ernst Strehlke, Leipzig 1874, s. 491; E. Keyser, Die Baugeschichte, s. 224. 
ckie łąki ${ }^{57}$. Taka identyfikacja przyznanego gruntu nie odpowiada jednak opisowi zawartemu w dokumentach, gdyż wówczas grobla wokół łąk i garbarnia, leżące w jednej linii, nie mogłyby wyznaczać dwóch różnych krawędzi opisywanego nadania.

Lokalizacja wskazana przez G. Köhlera rodzi także dalsze pytania. Czy rzeczywiście teren rysowanych przez badacza ogrodów, położonych między ul. Stajenną a Krosna, mógł należeć do Osieka w pierwszej połowie XV w.? Nie został przecież wpisany do księgi gruntowej Osieka założonej w 1584 r. a prowadzonej do $1814 \mathrm{r}$. Najstarszym zachowanym źródłem, w którym jest odnotowany jako „Rambawen Kirchhoff”, jest księga czynszowa Starego Miasta z 1495 r. ${ }^{58}$ W księdze z około 1400 r. nie był jeszcze ujęty ${ }^{59}$. Uwagę zwraca nie tylko fakt umieszczenia go w tej księdze, lecz także kolejność, w jakiej został zapisany. Wydają się one wskazywać, że obszar ten dopiero w drugiej połowie XV w. wszedł w obręb Starego Miasta, powiększając grunty przeznaczone pod zasiedlenie ${ }^{60}$.

Erich Keyser, przywołując ustalenia dokumentu z 1402 r., nie wskazał, o jaki fragment miasta mogło chodzić w zamianie. Jeśli uznać, że współpracował podczas wykonywania planów do pracy Friedricha Froesego, oznacza to, że miał jednak w tej kwestii podobne zdanie ${ }^{61}$.

Podobnie niejednoznaczna jest kwestia identyfikacji miejsca określonego w dokumencie z 1402 r. jako „Schild”. Skrajnym poglądem było jego przypisanie do wyspy, na której zbudowano Wielki Młyn, i która rzeczywiście nosi taką nazwę na jednym z nowożytnych planów ${ }^{62}$. Dla Augusta Bertlinga „Schild” był małą wysepką po wschodniej stronie ujścia młynówki do Wisły ${ }^{63}$. G. Köhler, a za nim inni badacze, jako poszukiwane miejsce wskazywali wyspę Brabank ${ }^{64}$. Pominęli milczeniem fakt, że miejsce to powinno było się znajdować u ujścia kanału Raduni do Motławy. Żadna z przedstawionych lokalizacji tego warunku nie spełnia. Z ogólnego sformułowania E. Keysera można wnioskować, że „Schild” znajdował się według niego przy Wiadrowni ${ }^{65}$.

${ }^{57}$ Trudno jednak zrozumieć dlaczego, jeśli by tak było, nie zostały one zaznaczone ani na planie Berndta z 1603 r., ani na planie z 1615 r., podczas gdy narysowano wały po zachodniej i północnej stronie Brabanku (1615).

${ }^{58}$ E. Keyser, Die Besiedlung der Altstadt Danzig, ZWG, H. 61: 1921, s. 189. Dopiero w tym czasie znajdowały się tu działki, które mogły zostać oczynszowane. Od końca XV w. zawsze ujmowany był w księgach Starego Miasta.

${ }^{59}$ J. Kaufmann, op.cit., s. 118-119.

${ }^{60}$ Pojawia się po wymienieniu wszystkich ulic starszej części Starego Miasta, a przed ulicami, które wytyczono po rozszerzeniu jego terytorium po $1455 \mathrm{r}$.

${ }^{61}$ Friedrich Froese, Die Entwicklung des Danziger Stadtbildes, Der Nordosten, Jg. 1: 1931, s. 158.

${ }^{62}$ APG, sygn. 300MP/6 (1637 r.), jest tu nazywana: „Das Mühlen Werder oder Schildt”.

${ }^{63}$ Biblioteka Gdańska PAN, sygn. C I 644. Plan rekonstrukcji układu przestrzennego Gdańska około 1382 r.

${ }^{64}$ G. KÖHLER, op.cit., Tafel II.

${ }^{65}$ E. KeYser, Die Baugeschichte, s. 376. 
Wskazane przeze mnie wątpliwości co do prawidłowości dotychczasowych interpretacji zapisów dokumentów z 1402 i 1425 r. skłoniły mnie do ponownej ich analizy. Pewne sformułowania użyte w dokumentach, kolejność, w jakiej wymieniane są obiekty, nie odpowiadają w pełni topografii wskazanych przez badaczy miejsc. Połączenie informacji zawartych w obu dokumentach pozwala na określenie powiązania przestrzennego między przywoływanymi w nich punktami topograficznymi. Wydaje się, że mamy do czynienia z następującą sekwencją obiektów położonych na wschód od rowu (biegnącego wzdłuż ul. Browarnej), w kolejności od południa ku północy: Osiek - nadany teren - garbarnia - nadany teren - łąka.

Moje zastrzeżenia znalazły ostatnio wsparcie w wynikach badań archeologicznych, które przyniosły ważne ustalenia co do lokalizacji krzyżackiej garbarni. Jej usytuowanie jest kluczowym elementem w identyfikacji nadanych gruntów, jako że przy niej znajdowało się miejsce, od którego rozpoczęto ich opis ${ }^{66}$. Umożliwia odtworzenie przestrzeni z czasów wydania obu dokumentów.

Podczas badań archeologicznych prowadzonych na stanowisku między ul. Browarną a Panieńską natrafiono na dwa prostopadłe do siebie kanały datowane na drugą połowę XIV w. Przy jednym z nich, o kierunku wschód-zachód i szerokości około $4 \mathrm{~m}$, biegnącym w odległości około $15 \mathrm{~m}$ od ul. Osiek, odkryto pozostałości drewnianego budynku zbudowanego na przełomie XIV i XV w., a nad kanałem podwalinę pod koło młyńskie o średnicy około 1,4 m. Przy podwalinie odsłonięto dużą ilość bardzo drobnej kory drzew liściastych, co - jak zaznaczyła autorka badań, Lidia Grzeszkiewicz-Kotlewska - świadczy o tym, że „zarówno koło młyńskie jak i budynek je zawierający były garbarnią, zaś obecność pieców i drobnych form kapeluszniczych może sugerować również funkcję dodatkową - folusza”.

Wydaje się nie ulegać wątpliwości, że odnaleziony obiekt można identyfikować z zaginioną krzyżacką garbarnią ${ }^{67}$. Jeśli w tym miejscu się znajdowała, to plac przyznany mieszkańcom Osieka musiał się rozciągać od okolic ul. Panieńskiej po kanał biegnący wzdłuż ul. Browarnej (il. 5). Jego granicę południową wyznaczała zabudowa Osieka a północną wał obiegający łąki ${ }^{68}$. W myśl dokumentu z 1425 r.

${ }^{66}$ Rzeczownik użyty dla określenia miejsca przy garbarni - „Steg” - nie jest jednoznaczny. Mógł oznaczać zarówno ścieżkę, jak i kładkę lub wąski pomost (http://woerterbuchnetz.de/DWB/ ?sigle=DWB\&mode=Vernetzung\&lemid=GS42201\#XGS42201; dostęp z 2 V 2015 r.), a także schody (http://woerterbuchnetz.de/Lexer/?sigle=Lexer\&mode=Vernetzung\&hitlist=\&patternlist= \&lemid=LS07134\#XLS07134; dostęp z 2 V 2015 r.).

${ }^{67}$ Garbarnia funkcjonowała jeszcze co najmniej w $1511 \mathrm{r}$. W księdze gruntowej Osieka z $1584 \mathrm{r}$. (APG, sygn. 300, 32/24, k. 23r), zachował się wpis zredagowany w 1464 r. (?), w którym jest ona przywoływana: „Der Heilige Geist hat ein garten gelegen bey dem Gerberhofe bey dem Schlosse den się gakaufft haben von Stephen Kiecke als Ihm Jacob Mierich gehabt hat. Actum Anno LXIIII". W świetle badań archeologicznych czas, w którym przestano ją użytkować, jest określony na około 1515 r. Miało to być związane z zamuleniem kanału, zob. L. Grzeszkiewicz-KotLewsKa, op.cit.

${ }^{68}$ Wydaje się, że około 1400 r. początkowy fragment ul. Panieńskiej i linia na jej przedłużeniu w kierunku Podwala Staromiejskiego stanowił granicę między wolą zamkową a Starym Miastem i Osiekiem. Wynika to ze spisu ulic księgi gruntowej Starego Miasta, zob. J. KaufmanN, op.cit., s. 118. Garbarnia znajdowałaby się wówczas na obszarze krzyżackiego folwarku ograniczonego od południa przez przebieg kanału opasującego wyniesienie wzdłuż ul. Podzamcze. 


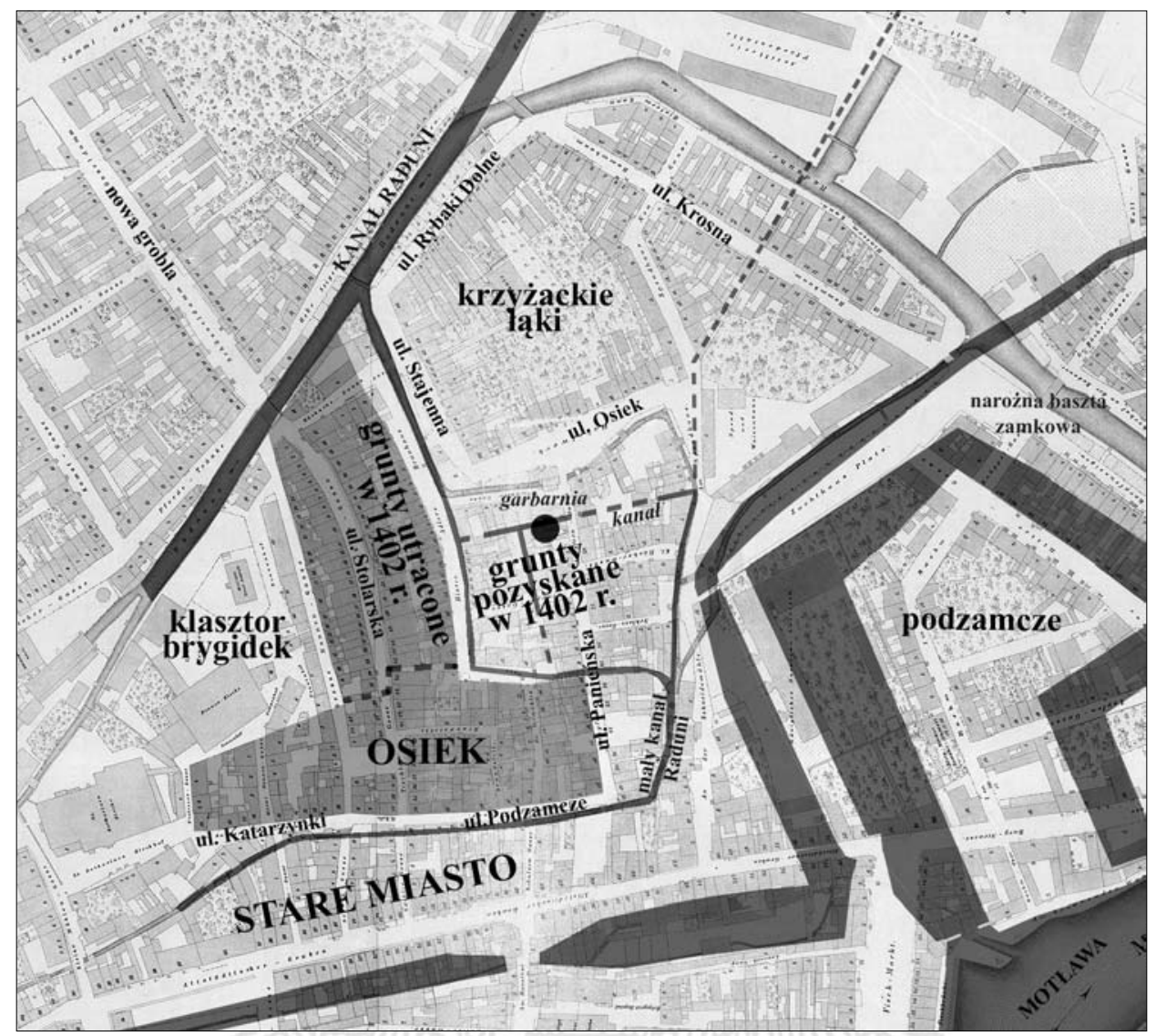

Il. 5. Położenie gruntów będących przedmiotem zamiany, garbarni oraz łąki krzyżackiej w 1402 r. Opracowanie autorki.

miejsce zajmowane przez łąki obwiedzione groblą miało się znajdować między garbarnią a młynówką. W dokumencie z 1402 r. podano ponadto, że graniczyło ono z kanałem poprowadzonym od młynówki do Osieka. Jeśli uznamy identyfikację garbarni za właściwą, to należałoby przyjąć, że łąki zajmowały obszar objęty późniejszymi ulicami: Stare Domki, Osiek, Stajenna i Rybaki Dolne. Takie usytuowanie spełniałoby także kryteria zawarte w umowie z 1425 r. - na łąki przechodziłoby się bezpośrednio z drogi poprowadzonej po zachodniej stronie kanału biegnącego od Osieka do młynówki. Znaczna szerokość ulic Osiek i Stajennej, a także odległość pierzei południowej ul. Rybaki Dolne od krawędzi młynówki byłyby wówczas śladem po przebiegu grobli. Tak przyjętą identyfikację terenów objętych przywilejami z 1402 i 1425 r. potwierdza także kilka innych przesłanek. Wyniki cytowanych badań archeologicznych wskazują, że pierwszy budynek na tak zakreślonym obszarze nadania pojawił się dopiero w drugiej połowie XIV w.; kolejny dopiero pod koniec tego wieku. Również późne zasiedlenie hipotetyczne- 
go obszaru dawnych łąk (koniec XV w.) zdaje się potwierdzać jego wcześniejsze wykorzystywanie na inne cele niż mieszkalne ${ }^{69}$.

Po omówieniu przypuszczalnej lokalizacji dwóch obszarów wymienianych w umowach z 1402 i 1425 r. - placu przyznanego Osiekowi i łąki krzyżackiej chciałabym przedstawić moje rozważania na temat usytuowania miejsca, w którym rybacy z Osieka mogli trzymać swoje łodzie i suszyć sieci. Jak wspomniałam, poza T. Hirschem, który identyfikował je z niezabudowanym trójkątnym fragmentem wyspy, na której znajdował się Wielki Młyn, wszyscy badacze są zdania, że był on tożsamy z wyspą Brabank, leżącą u ujścia Motławy do Wisły. Jak zaznaczyłam, moje zastrzeżenie co do tej hipotezy budzi przede wszystkim stwierdzenie, że miejsce to - jak wynika z treści dokumentu z 1402 r. - winno było się znajdować u ujścia Raduni do Motławy.

Zapis o tym, że Radunia wpływała do Motławy, w świetle siedemnastowiecznych planów tych okolic nie znajduje bezpośredniego potwierdzenia. Z planu Berndta z 1603 r. wynika, że Radunia wpływała w tym czasie do Wisły. Końcowy fragment kanału meandrował, jednak jeszcze przed sporządzeniem tego planu został poprowadzony w linii prostej. Do kanału młyńskiego od strony wschodniej dochodził inny kanał - zwany później Kanałem Wiadrowników (Eimermachergraben, nazwa ta pojawiła się dopiero w XVI w.). Z końcowym fragmentem młynówki i Motławy odcinał wyspę Brabank od stałego lądu. Jak z tego wynika, młynówka nie uchodziła wówczas do Motławy.

Młynówka wpadałaby do Motławy, jeśliby uznać, że w średniowieczu kanał Wiadrowników z końcowym fragmentem meandrującej „Alter Radaun” stanowił jedną z dwóch odnóg Motławy. Kanał Wiadrowników, co wyraźnie widać na nowożytnych planach, na rozwidleniu za terenem Zamczyska miał znaczną szerokość. Zaczęto go zawężać dopiero w XVII w. na skutek nadsypywania gruntu od strony Wiadrowni i Brabanku ${ }^{70}$. Jeśli Kanał Wiadrowników byłby tożsamy z Motławą z dokumentu z 1402 r., to terenu określanego mianem "Schild” należałoby szukać po jego zachodniej, a nie wschodniej stronie. Jak wspomniałam, E. Keyser także widział to miejsce w pobliżu siedliska wiadrowników. Nie musiał to być koniecznie teren o kształcie tarczy ${ }^{71}$. O tym, że ten właśnie teren mógł być określony jako „Schild”, świadczy jeszcze jedna przesłanka. Miał się on znajdować po drugiej stronie łąk. Czytając ten fragment, odnosi się wrażenie, że bezpośrednio z nim sąsiadowały. W opisie nie ma mowy o ewentualnym kanale, który by je rozdzielał

${ }^{69}$ Lokalizacja w tym miejscu cmentarza czeka na potwierdzenie w badaniach archeologicznych. Działki na opisanym obszarze wymieniane są w księgach gruntowych dopiero od 1566 r., zob. APG, sygn. 300, 32/23, k. 142r. Zabudowa wzdłuż obwiednich ulic widoczna jest także na sztokholmskim planie z około $1600 \mathrm{r}$.

${ }^{70}$ Są to ustalenia będące wynikiem badań archeologicznych prowadzonych przez Agencję „DART” Jacek Gzowski na Wiadrowni w latach 2011-2012.

71 http://woerterbuchnetz.de/DWB/?sigle=DWB\&mode=Vernetzung\&lemid=GS08534\#XGS 08534 (dostęp z 7 II 2015 r.): „,in einem volksrätsel zur bezeichnung einer bodenerhebung” lub „zur bezeichnung dreieckiger plätze". 


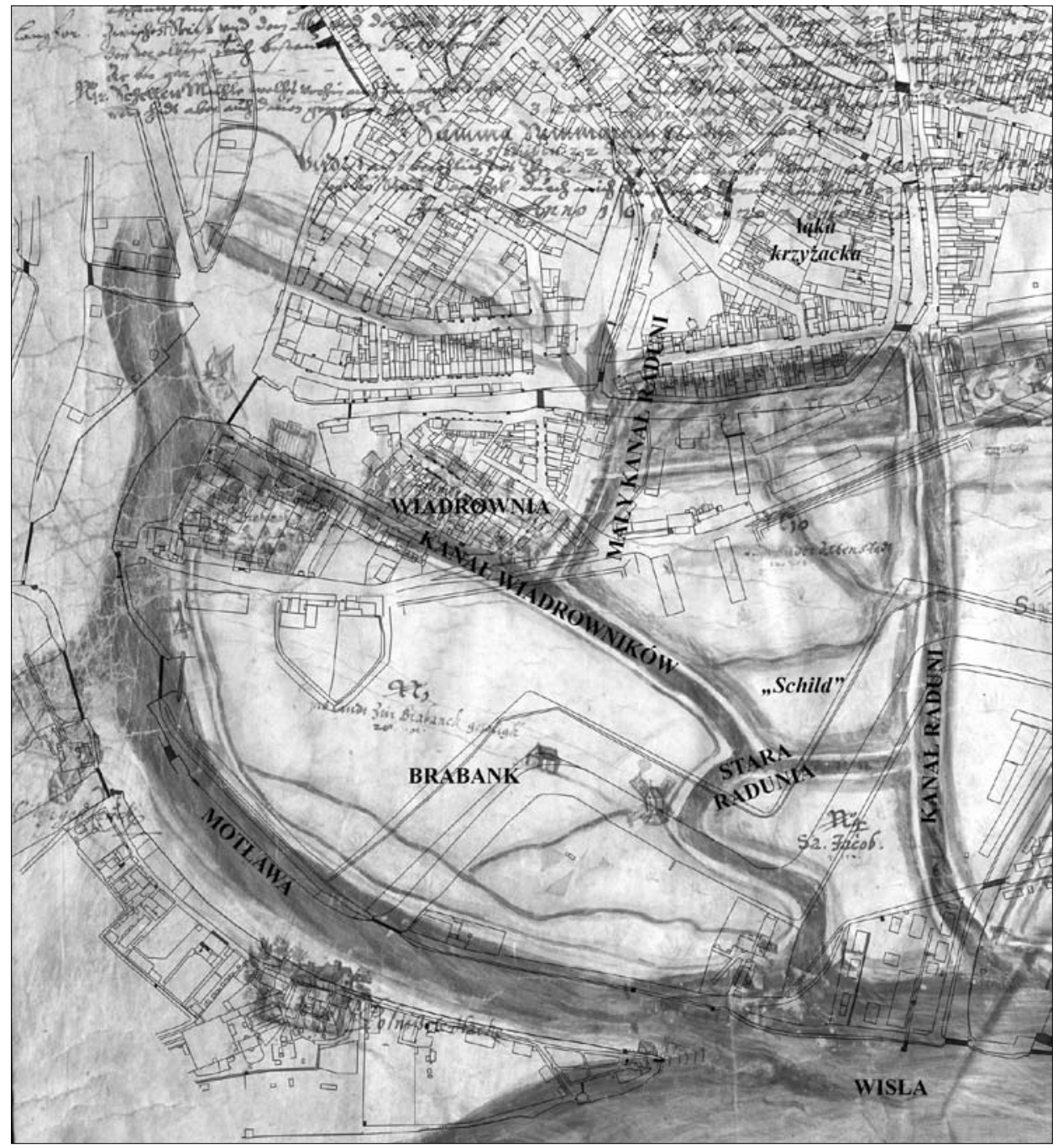

Il. 6. Fragment planu Berndta z 1603 r. nałożony na odpowiedni fragment przerysu planu Buhsego. Opracowanie autorki. Przerys planu Buhsego został wykonany w ramach grantu Narodowego Centrum Nauki, nr NN 108253538.

- a tak by być musiało, jeśli poszukiwanemu miejscu odpowiadałaby wyspa Brabank. Wskazana przeze mnie lokalizacja byłaby o wiele bardziej racjonalna - rybacy, by dostać się do swoich łodzi i sieci, nie musieliby przeprawiać się przez dość szeroki kanał, co byłoby konieczne w przypadku lokalizacji proponowanej przez G. Köhlera.

Jak wynika z przedstawionych rozważań, można mieć wątpliwości co do lokalizacji czternastowiecznego Osieka w obrębie czworoboku objętego kanałami, $\mathrm{z}$ centrum przy ul. Panieńskiej. Według mnie właśnie ten teren (około połowy XIV w. zabudowany co najwyżej luźno) został przyznany Osiekowi w całości lub 
w części zachodniej w 1402 r. Wcześniej przeprowadzono jego meliorację, gdyż jako podmokły nie nadawał się pod zasiedlenie. Czternastowieczny Osiek mógł więc być położony na południe i zachód od niego. Jego nową piętnastowieczną część przecięly z czasem krzyżujące się pod kątem prostym ulice: Panieńska (Jungferngasse) i obecnie nieistniejące Kumoszek (Plappergasse), Piekary Małe (Kleine Bäckergasse), Zamkowa (Schlossgasse). Objął więc cały teren ujęty w księdze gruntowej z $1584 \mathrm{r}^{72}$

Zagospodarowanie obszaru położonego na północ od garbarni, zajętego w moim przekonaniu w średniowieczu przez krzyżackie łąki, rozpoczęto dopiero w końcu XV w. W miejscu grobli wytyczono ulice, których zasiedlenie było daleko zaawansowane $\mathrm{w}$ końcu XV $\mathrm{w}^{73}$ Mimo pojawienia się w pobliżu zabudowy mieszkalnej garbarnia pokrzyżacka funkcjonowała co najmniej do pierwszej ćwierci XVI w. W końcu tego wieku kanał, nad którym się znajdowała, uległ zamuleniu. Być może już wcześniej wytyczono nowy jego przebieg na północ od zasiedlonego obszaru, po raz pierwszy widoczny na aksonometrycznym planie z około 1600 r., znany także z licznych innych nowożytnych planów Gdańska. Kolejne zmiany przyniosły lata trzydzieste XVII w., kiedy na skutek budowy nowego obwodu fortyfikacji zadecydowano o wpuszczeniu wód Kanału Raduni do Motławy i wytyczono w miejscu starego wału, wzdłuż jego końcowego odcinka, kolejną ulicę: Krosna (il. 6).

Dziś po dawnej topografii tego fragmentu miasta pozostało niewiele śladów. Niezmieniony pozostał przebieg ulic: Stare Domki, Sierocej, Stajennej, Osiek i Rybaki Dolne. Próżno jednak szukać pozostałych. W trakcie powojennej odbudowy miasta zrezygnowano $\mathrm{z}$ zachowania wielu starych ciągów ulicznych, upraszczając dawną plątaninę wąskich uliczek. Zasypano końcowy fragment małego kanału Raduni. Dawny układ tego miejsca przetrwał jedynie w starych planach. Odkrywany jest także podczas prac archeologicznych. Ich rozszerzenie, przewidziane w przyszłości w rejonie ul. Panieńskiej, wyjaśni być może ostatecznie wszelkie wątpliwości związane z początkami tej dzielnicy Gdańska.

\section{dr Zofia Maciakowska}

Instytut Historii PAN

e-mail: zofiam@poczta.onet.eu

${ }^{72}$ Zob. przyp. 2. Zestawienia działek dokonano na podstawie adnotacji wprowadzonych do księgi przez nieznanego badacza, który poszczególnym wpisom przyporządkował współczesną mu numerację, umożliwiającą identyfikację nieruchomości w przestrzeni Osieka. Nie wiadomo jednak, na jakiej podstawie tego dokonał i czy identyfikacja została w pełni właściwie przeprowadzona. W księdze nie ujęto już gruntów odstąpionych brygidkom w $1449 \mathrm{r}$.

${ }^{73}$ Wskazuje na to spis szosu z 1495 r., zob. E. KeYsER, Die Baugeschichte, s. 514. 
EINIGE BEMERKUNGEN ZUM MITTELALTERLICHEN STADTTEIL OSIEK (HAKELWERK) IN DANZIG

\section{Zusammenfassung}

Schlüsselbegriffe: Danzig, Osiek, Mittelalter, Besiedlung, Radaune-Kanal

An Hakelwerk (Osiek), einst eine selbstständige Stadtgemeinde von Danzig, erinnert heute nur noch ein Straßenname. Über ihre Geschichte und das Gebiet, auf dem sie sich erstreckte, ist relativ wenig bekannt. Dies liegt daran, dass sich nur wenige Urkunden erhalten haben, in denen sie vorkommt. 1402 führten die Ritter des Deutschen Ordens einen Austausch von Grundstücken mit den Einwohnern von Hakelwerk durch. Für ein Gelände, das an der „nue gasse“, heute ul. Stolarska, lag, erhielten die Einwohner von Hakelwerk zur Besiedlung einen Platz, der in der Nähe der Gerberei des Ordens lag, außerdem einen Liegeplatz für Schiffe und zum Trocknen von Netzen („Schild“). Zusätzliche Informationen zu dieser Verleihung findet man in einer Urkunde von 1425.

Die Einzelheiten in den Angaben der beiden Urkunden sind schwer auf die heute völlig veränderte Topographie dieses Stadtteils zu beziehen. Meistens hat man das für die Besiedlung bestimmte Gelände in einem Gebiet gesehen, das nördlich der ul. Osiek (Hakelwerk) und östlich der Umgebung der ul. Panieńska (Jungfergasse) liegt. Als den verlorenen „Schild“ identifizierte man die Insel Brabank. Der erste, der diese Lokalisierung vornahm, war Gustav Köhler.

Die Ergebnisse von archäologischen Untersuchungen, die in den Jahren 2007 und 2011 zwischen der ul. Panieńska und der ul. Osiek durchgeführt wurden, haben die bisherigen Befunde in Frage gestellt. Am Zusammentreffen dieser Straßen wurde eine Gerberei gefunden, die an der Wende vom 14. zum 15. Jahrhundert errichtet wurde. Sie stand über einem heute nicht mehr existierenden Kanal. Ihre Lage weist darauf hin, dass das für die Besiedlung bestimmte Gebiet sich zwischen der ul. Panieńska und der ul. Browarna befunden haben muss, in der Nähe der heute nicht mehr existierenden ul. Podzamcze (Burggrafen-Straße) und der ul. Osiek. Das zweite Element des Vertrags, der „Schild“, wäre dann im Gebiet der Mündung des Eimermacher-Kanals in die Alte Radaune, auf der westlichen Seite des Kanals, zu lokalisieren. 
A FEW REMARKS ABOUT MEDIEVAL OSIEK (HAKELWERK) IN GDAŃSK

Summary

Key words: Gdansk, Osiek, the Middle Ages, settlement, Radunia Channel

What remains of Osiek [Hakelwerk], which in the past was an independent borough of the city of Gdansk, is only the name of the street. Relatively little is known about its history and the territory which it occupied, for there are few preserved documents mentioning it. In 1402 the Teutonic Knights exchanged land with the inhabitants of Osiek. In exchange for the territory situated along "nue gasse", which is now Stolarska street, the inhabitants of Osiek received a square located near the Teutonic tannery and a place to keep boats and dry nets ("Schild"). Additional information about the territory granted to them may be found in a document from 1425 .

Details included in both documents hardly correspond to the completely altered topography of this part of the city. The area north of Osiek street (Hakelwerk) and east of Panienska street (Jungfergasse) was considered to be designed for settlement. The island of Brabank was to become the now lost "Schild". The location was first indicated by Gustav Köhler.

The results of archeological research conducted in the years 2007 and 2011 between Panieńska street and Osiek allow us to question the hitherto established findings. Near the crossroads of both streets a tannery built at the turn of the 14th and 15th centuries was discovered. It was situated at a channel which does not exist any more. Its location indicates that the area designed for settlement is most likely to have been between Panienska street and Browarna street in the vicinity of the now non-existent Podzamcze street (Burggrafen) and Osiek street. The second element of the layout - "schild" - could have been located at the mouth of the Wiadrowniki Channel up to "Stara Radunia" on the western side of the channel. 